\title{
Counting Enchytraeus crypticus Juveniles in Chronic Exposures: An Alternative Method for Ecotoxicity Studies Using Tropical Artificial Soil
}

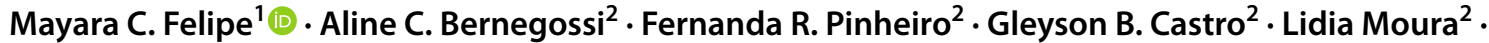 \\ Marcelo Zaiat $^{1}$. Juliano J. Corbi ${ }^{2}$
}

Received: 22 January 2021 / Accepted: 28 June 2021 / Published online: 16 July 2021

(c) The Author(s), under exclusive licence to Springer Science+Business Media, LLC, part of Springer Nature 2021

\begin{abstract}
Soil toxicity tests are commonly applied using Enchytraeus crypticus to analyze reproductive outputs. However, the traditional method for counting potworms takes a long time due to the significant number of offspring. This paper compares the conventional total counting of E. crypticus juveniles (M1) and an alternative methodology (M2). The proposed methodology (M2) uses a simple random counting method (1/4) for the partial counting of juveniles and total estimation. Chronic bioassays (21 days of exposure) were performed in tropical artificial soil (TAS) using sugarcane vinasse as a hazardous substance. Comparing the final density of juveniles recorded in M1 and M2, no statistical differences were pointed out in either one. Applying analyses based on effective concentration (EC10 and EC50), no statistical differences were identified there either. The t-test showed that there was no statistical difference between the counting methods (M1 and M2) in each treatment (control and dilutions). Moreover, we ran the Tukey test for M1 and M2 methods separately and observed that $100 \%$ of the vinasse showed a statistical difference compared to the control treatment in both $(p \leq 0.05)$, affirming that independent of the counting method, the ecotoxicological outputs were similar. Therefore, the proposed alternative is a suitable method for bioassay using. E. crypticus in tropical artificial soil, decreasing to $1 / 4$ the total time required for counting.
\end{abstract}

Keywords Enchytraeid $\cdot$ Potworms $\cdot$ Counting juveniles $\cdot$ Time optimization $\cdot$ Soil toxicity

Ecotoxicology is a science addressed to understand the effects of natural and anthropogenic agents on biota and its representatives (Newman 2009; Zhou et al. 2018). It is scientifically recognized that biological responses are better tools for predicting the behavior of the stressors towards ecosystems rather than physical and chemical analysis (Zaghloul et al. 2020). Earthworms are the most used organisms in terrestrial bioassessments in Latin America (Niemeyer et al. 2017). In this sense, oligochaetes have played

Mayara C. Felipe

mayarafelipe@usp.br

1 Biological Processes Laboratory (LPB), Department of Hydraulic and Sanitation, São Carlos School of Engineering (EESC), University of São Paulo (USP), Av. João Dagnone, 1100, Santa Angelina, São Carlos, Brazil

2 Aquatic Ecology Laboratory (LEAA), Department of Hydraulic and Sanitation, São Carlos School of Engineering (EESC), University of São Paulo (USP), Av. João Dagnone, 1100, Santa Angelina, São Carlos, Brazil an important role as bioindicators of pollutant toxicity due to their sensitivity to specific toxicants and certain tolerance to pollution (Chapman 2001; Sivakumar 2015; Castro et al. 2020a; Castro et al. 2020b; Felipe et al. 2020).

Among the Oligochaeta, enchytraeids are important soil fauna components, acting as nutrient-cycling organisms and resulting in better soil porosity and fertility, either by their movement or their fecal deposition (Topoliantz et al. 2000; Jänsch et al. 2005; Rombke et al. 2017). Enchytraeus crypticus Westheide and Graefe (1992) showed significant applicability in acute and chronic bioassays due to its sensitivity (Hrdá et al. 2016; Lahive et al. 2019; Da Rocha et al. 2020), especially by downsizing the shorter life-cycle and higher reproduction response for chronic assessments among the enchytraeids family (Castro-Ferreira et al. 2012). The use of standard artificial soil and the inclusion of alternative substrates more abundant in the study area (e.g. coir pith and coconut fiber for tropical regions) is indicated to recover results with more validity in ecotoxicological bioassays (Abbiramy et al. 2012; ABNT 2014). 
The consolidation of ecotoxicology as a scientific subsidy for risk assessments increased the demand for bioassays and required an acceleration in the obtained responses from organisms. As broadly known by soil ecotoxicologists, the enchytraeid reproduction test takes a great investment of time by manually counting the organisms that can reach over a thousand new individuals per replicate (Droge et al. 2006; Bicho et al. 2015; Testa et al. 2020). Matějů et al. (2014) addressed this issue by proposing counting E. crypticus juveniles by floating worms from samples, using chemical additives, photographing them, and employing software applications for digital calculation.

Different counting methods were tested and proven in order to better approximate the piece to the whole studied object (DePatta Pillar 1998; Elphick 2008; Chao et al. 2009), and the technique selection is usually considered a costeffective strategy (Mode et al. 1999). Simple random counting and its variants were broadly applied with reliable performance and low economic demands over the time to estimate population diversity and density (Bourdeau 1953; Goedickemeier et al. 1997; Chu et al. 2018) and have been used in ecological studies (Antoniolli et al. 2006; Henderson 2009).

This paper presents an alternative random counting procedure for soil ecotoxicological outputs obtained by the $E$. crypticus reproduction test to reduce the time spent in the manual counting of juveniles with no extra costs in devices or facilities. To validate this alternative method, we tested the statistical resemblance between the conventional total counting of E. crypticus juveniles suggested (M1) and an alternative methodology (M2), that consists of simple random counting (1/4) for the partial counting of juveniles and total estimation. The sugarcane vinasse was used as a contaminant because it is a commonly used subproduct of the sugarcane industry that is usually applied for fertirrigation in countries in tropical zones (Fuess and Garcia 2014; Fuess et al. 2017).

\section{Materials and Methods}

Enchytraeus crypticus (Annelida; Oligochaeta; Enchytraeidae) were obtained from the Laboratory of Ecotoxicology at the Center for Water Resources and Environmental Studies (CRHEA) and were maintained at the Aquatic Ecology Laboratory (LEAA), both in the São Carlos School of Engineering, University of São Paulo, Brazil (EESC/USP). Species cultivation was kept in substrate Bacto-Agar medium plates prepared with a sterilized mixture of salt solution containing $\mathrm{CaCl}_{2} \cdot 2 \mathrm{H}_{2} \mathrm{O}$ (calcium chloride dihydrate $-29.4 \mathrm{~g} / \mathrm{L}$ ), $\mathrm{KCl}$ (potassium chloride $-0.74 \mathrm{~g} / \mathrm{L}$ ), $\mathrm{NaHCO}_{3}$ (sodium hydrogen carbonate $-8.4 \mathrm{~g} / \mathrm{L}$ ), and $\mathrm{MgSO}_{4} 7 \mathrm{H}_{2} \mathrm{O}$ (magnesium sulfate heptahydrate $-12.3 \mathrm{~g} / \mathrm{L}$ ). The potworms were fed $10 \mathrm{mg}$ of oatmeal two times a week and maintained under $20 \pm 2{ }^{\circ} \mathrm{C}$ and a 16:8 h light-dark cycle.

Enchytraeus crypticus exposure experiments were based on OECD protocol n. 220 entitled "Enchytraeid Reproduction Test" (OECD 2016). According to the protocol, the determination of adult mortality, the estimate of the number of juveniles, the measure of soil $\mathrm{pH}$, and the moisture content can be assessed over 21 days.

The assays were performed using tropical artificial soil (TAS) of NBR ISO 16,387 (ABNT 2012), also based on the soil recommended by the OECD (1984) protocol, that consists of a mixture of sand, white clay (kaolin), and coconut fiber powder (70:20:10, dry weight). As proposed by the OECD (2016), the water holding capacity was maintained at $60 \%$ by the addition of filtered water (control treatment) (USEPA 2002) or dilutions of sugarcane vinasse (liquid substance treatments). Dilutions of sugarcane vinasse in filtered water were assembled in the proportion of $0.1 \%, 5 \%$, $10 \%, 50 \%$ and $100 \%$ (raw vinasse), named as V0.1, V5, V10, V50 and V100, respectively (Botelho et al. 2012). Due to the critical scenario of the COVID-19 pandemic in Brazil, experiments testing red oxisol soil have not been completed, but are recommended in further studies.

After the humidification, $30 \mathrm{~g}$ of the tested soil was transferred to cylindrical plastic vessels $(6.3 \mathrm{~cm}$ high inner diameter $5.8 \mathrm{~cm}$ ) in each replicate (three replicates were used for each treatment). Then, 10 enchytraeids adult organisms with visible clitellum (length size of approximately $7 \mathrm{~mm}$ ), checked by visual observation by stereoscope microscope, were collected from cultivation and allocated in the treatments. Subsequently, $10 \mathrm{mg}$ of oatmeal was distributed in all replicates. The test containers were closed, and the time of exposure started. The individuals were exposed for 21 days, and test containers were opened after 7 and 14 days for feeding and adding filtered water when necessary (maintaining the $60 \%$ humidity). The containers were kept at $20 \pm 2{ }^{\circ} \mathrm{C}$ and a 16:8 h light-dark cycle. After 3 weeks, all samples were fixed by adding $40 \mathrm{~mL}$ of $96 \%$ ethanol and colored with $300 \mu \mathrm{L}$ of rose Bengal (CAS 632-69-9) solution (1\% in ethanol). The coconut fiber was not colored, and therefore, only potworms were highlighted in the samples.

After the potworms had been properly colored, all samples were carefully sieved $(150 \mu \mathrm{m})$ and washed with tap water for $40 \mathrm{~s}$ to separate the enchytraeids from the smaller particles of TAS. Subsequently, the samples were transferred into white trays $(36 \mathrm{~cm} \times 23 \mathrm{~cm})$. In order to remove the remaining material from the sieve, $1 \mathrm{~L}$ of tap water was poured against its bottom, and the tray was positioned on a lightbox. All juveniles were visually identified, separated with Pasteur pipette, confirmed with a stereoscope microscope, and the final density recorded to obtain the total number of juveniles per replicate (OECD 2016). 
The procedures for washing time, sifting, and adding $1 \mathrm{~L}$ of tap water on white trays $(36 \times 23 \mathrm{~cm})$ were the same performed in the traditional counting method (OECD 2004). The white tray was divided into four fractions, previously marked on the bottom with a permanent pen into four equal quadrants $(9 \mathrm{~cm} \times 23 \mathrm{~cm})$, to guide the counting of stained enchytraeids. The next step was based on simple random sampling (Kaur et al. 1996; Gregoire and Affleck 2018). Afterward, each sample was slightly agitated and manually spread using a Pasteur pipette to avoid possible sediment agglomeration in the tray until its whole area could be homogeneously occupied by the sample. After the withdrawal of all adults, a draw was made to select one of the four quadrants to be counted. After counting the juveniles in the selected quadrant, the total number of juveniles was estimated (Eq. 1).

$T M_{M 2}=I c \times n Q$

$\mathrm{Td}=$ Total density of potworm juveniles estimated; Ic $=$ number of individuals counted in the drawn quadrant; $\mathrm{nQ}=$ number of quadrants.

To validate the application of the counting method, we applied a two-group comparison analysis (Student's t-test) for each treatment (controls and vinasse dilution), comparing the density recorded in the conventional (M1) and alternative (M2) counting methods. Also, to evaluate if the counting method influences the bioassays analysis, the ANOVA test was applied for each method, comparing the results from the control and vinasse dilution treatments. Statistical tests were performed on Past software, version 3.25 (Hammer et al. 2001) considering a significance level of $95 \%$. Moreover, the effective concentration that affects $10 \%$ and $50 \%$ of the reproduction rate (EC10 and EC50, respectively) was calculated using R software and packages MASS and DRC (R Core Team 2014). The EC results for both methods were compared by t-test to assess the similarity of the results $(p>0.05)$.

\section{Results and Discussion}

Descriptive results from chronic ecotoxicological tests are presented in Fig. 1. In general, the number of E. crypticus juveniles estimated in $\mathrm{M} 2$ is covered by the standard deviation of the total density obtained in M1. Based on ANOVA results, the treatment that affected the reproduction rate of the individuals compared to the control was the raw sugarcane vinasse V100. Checking the correspondence between M1 and M2, the t-test showed statistical resemblance in the total number of juveniles between the two methods for all treatments ( $p$-value $>0.05$, Table 1$)$.

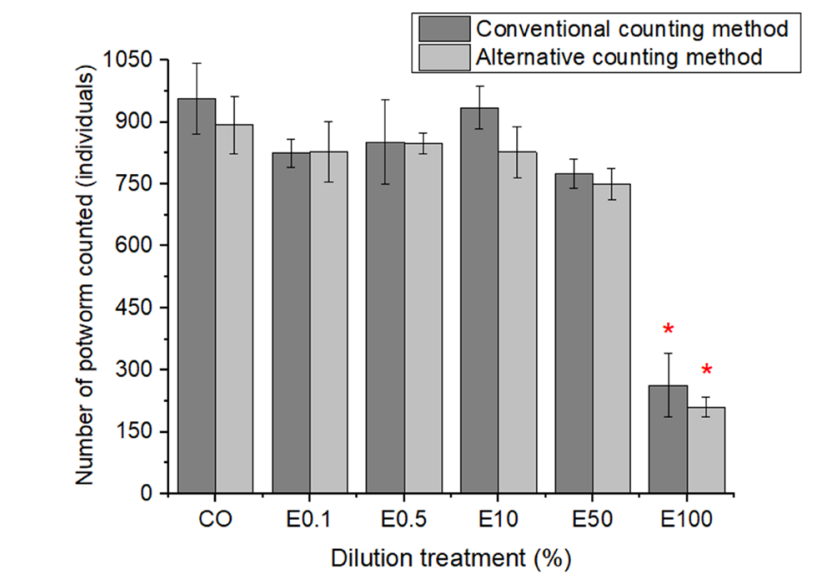

* statistical difference with control treatment

Fig. 1 Density of E. crypticus juveniles at the closure of chronic exposure, using a conventional counting method (M1) and alternative counting method (M2). *Statistical difference with control treatment

Moreover, the conventional statistical analysis in both methods demonstrated similar results and interpretations. As the results followed a normality distribution, ANOVA test was applied, and the results for the M1 and M2 reproduction rate indicates differences between the control and vinasse dilutions ( $p$-value of $3.84 \times 10^{-07}$ and $1.65 \times 10^{-08}$, respectively). In both methods, significant differences in the density of worms between treatments were indicated for V100 ( $p$-value $\leq 0.05$ ), according to the Tukey test. Furthermore, the EC10 and EC50 for M1 and M2 showed a high resemblance: EC10 of 46.35 and $48.14 \%$; and EC50 of $80.39 \%$ and $78.25 \%$, respectively. The t-test showed that these values are not statistically different $(p>0.05)$.

Due to the great number of juveniles generated during chronic exposure using E. crypticus, the traditional manual counting procedure was extensively laborious, lasting an average of $120 \mathrm{~min}$ per replicate. Traunspurger et al. (2009) reported difficulties in obtaining the final number of juveniles per adult in whole sediments using Caenorhabditis elegans and highlighted the importance of caution when counting individuals within such extensive periods. Nonetheless, such tests are dependent on the visual capability of each counter, and the size of juveniles is detectable with a naked eye. Some other approaches use stereoscopes to scan the sample (Alves et al. 2015) or a series of washing processes through a sieve to better identify the juveniles (Bicho et al. 2016). Whatever strategy is adopted, the results could be inaccurate by the exhaustion of the researcher, and tests that require a long time to count individuals often cause insecurities about the number raised.

Within the enchytraeid family, when comparing the number of juveniles reproduced per adult individual, $E$. crypticus had a higher reproduction rate than E. albidus 
Table 1 Comparison between the total density of potworms recovered in control and vinasse dilution treatments by conventional counting method (M1) and alternative counting method (M2) using t-test, considering a confidence interval of 95\%

\begin{tabular}{|c|c|c|c|c|c|}
\hline \multirow[t]{2}{*}{ Dilution treatment } & \multirow{2}{*}{$\begin{array}{l}\text { Conventional } \\
\text { counting method } \\
\text { (M1) } \\
\text { Total density } \\
\text { of potworms } \\
\left(\mathrm{TD}_{\mathrm{M} 1}\right)\end{array}$} & \multicolumn{3}{|c|}{ Alternative counting method (M2) } & \multirow{2}{*}{$\begin{array}{l}\text { Comparison } \\
\text { between } \mathrm{TD}_{\mathrm{M} 1} \text { and } \\
\mathrm{TD}_{\mathrm{M} 2} \\
\text { (t-test } p \text {-value) }\end{array}$} \\
\hline & & $\begin{array}{l}\text { Randomly drawn } \\
\text { quadrant }\end{array}$ & $\begin{array}{l}\text { Density of potworms counted in } \\
\text { the drawn quadrant (Ic) }\end{array}$ & $\begin{array}{l}\text { Estimated total potworms } \\
\text { density }\left(\mathrm{TD}_{\mathrm{M} 2}\right)\end{array}$ & \\
\hline \multirow[t]{3}{*}{ Control } & 991 & 3 & 206 & 824 & \multirow[t]{3}{*}{0.374} \\
\hline & 1020 & 2 & 223 & 892 & \\
\hline & 860 & 1 & 241 & 964 & \\
\hline \multirow[t]{3}{*}{ V0.1 } & 823 & 1 & 226 & 904 & \multirow[t]{3}{*}{0.935} \\
\hline & 860 & 2 & 189 & 758 & \\
\hline & 793 & 4 & 206 & 826 & \\
\hline \multirow[t]{3}{*}{ V5 } & 940 & 3 & 210 & 840 & \multirow[t]{3}{*}{0.959} \\
\hline & 875 & 1 & 207 & 828 & \\
\hline & 739 & 4 & 219 & 876 & \\
\hline \multirow[t]{3}{*}{ V10 } & 950 & 3 & 204 & 816 & \multirow[t]{3}{*}{0.081} \\
\hline & 977 & 2 & 193 & 772 & \\
\hline & 878 & 2 & 224 & 894 & \\
\hline \multirow[t]{3}{*}{ V50 } & 742 & 4 & 180 & 720 & \multirow[t]{3}{*}{0.454} \\
\hline & 813 & 3 & 185 & 740 & \\
\hline & 771 & 1 & 198 & 792 & \\
\hline \multirow[t]{3}{*}{ V100 } & 228 & 2 & 50 & 200 & \multirow[t]{3}{*}{0.323} \\
\hline & 210 & 4 & 48 & 194 & \\
\hline & 352 & 3 & 59 & 238 & \\
\hline
\end{tabular}

(Castro-Ferreira et al. 2012). This report helped to consolidate the reduction of the test exposure period for this species, exemplifying the necessity of continuous revisions and fair adaptations of bioassessments' demands of time. In cases of an overpopulated sample, rather than gross values, statistical results are a clearer indicator of impact since what appears to be a great number could not necessarily be interpreted as a perturbation when compared with the control situation, which could only be scaled and quantified in statistical comparisons. Applying a less tiresome approach could optimize the counting of all juveniles in the selected area and demonstrate the same statistical difference.

Domene et al. (2011) reported a growing interest in developing an alternative ecotoxicological assessment that overcomes the reproduction as the final result for potworms, as currently some extra analysis can be performed such as gene expression (Gomes et al. 2018), feeding activity (Bart et al. 2018), avoidance behavior (Pflugmacher et al. 2020), and Kinect uptaking (Mendonça et al. 2020). Although these advanced techniques are valuable in bioassessment, some of them need the basal values of effective concentrations generated by the reproduction test to deepen their analysis. Rombke (2003) pointed out the necessity of innovation with the counting method, especially by software image scan, which was accomplished by Matějů et al. (2014) with a computational image detection of the stained worms and a time savings although high-quality equipment and handling of other chemicals are required. The alternative method proposed in this study provided a reduction in the counting time of juveniles, demanding an average of $30 \mathrm{~min}$ per replicate and without additional financial costs.

In conclusion, this study presented an alternative counting method for the counting of E. crypticus juveniles in a reproduction test. The counting method suggested by traditional protocols showed no statistical difference from the proposed alternative methodology. Therefore, focusing on obtaining a faster counting method with no additional costs, decreasing to $1 / 4$ of the total time required in traditional counting and ensuring equivalent results, the alternative counting method is an efficient technique to support the counting of E. crypticus in reproduction tests, using a representative soil of ecotoxicological bioassays in tropical environments. In addition, bioassays using different types of soils are recommended as well for applying our alternative counting method, and similar results to those observed in this study are expected.

Acknowledgements We are grateful to the São Paulo Research Foundation (FAPESP - Grants\# 2018/21901-0, and 2015/06246-7), the National Council for Scientific and Technological Development 
(CNPq - Grant\# 131610/ 2018-0), and the Brazilian Coordination for the Improvement of Higher Education Personnel (CAPES - Grants\# 88887.353028/2019-00, 88887.352964/2019-00 and $88887.339518 / 2019-00)$, for financing this research.

\section{References}

Abbiramy KS, Ronald RP, Thenmozhi P, Muthulingam M, Paramananandham J, ManoharanV (2012) The validation of modified tropical artificial soil by ecotoxicological studies on Eisenia foetida. Int Jour Dev Res 2(5):1051-1056

ABNT (Associação Brasileira de Normas Técnicas) (2012) NBR ISO 16387 Soil quality - effects of pollutants on enchytraeidae (enchytraeus sp.) - determination of effects on reproduction and survival

ABNT (Associação Brasileira de Normas Técnicas) (2014) Qualidade do solo - Determinação dos efeitos de poluentes na flora terrestre Parte 2: Efeitos do solo contaminado na emergência e no crescimento inicial de vegetais superiores. https://www.abntcatalo go.com.br/norma.aspx? ID $=323872$

Alves PRL, Natal-da-Luz T, Sousa JP, Cardoso EJBN (2015) Ecotoxicological characterization of sugarcane vinasses when applied to tropical soils. Sci Tot Environ 526:222-232

Antoniolli ZI, Conceição PC, BöcK V, Por O, da Silva MD, da Silva RF (2006) Alternative method to study soil edaphic fauna. Ciência Florestal 16:407-417. https://doi.org/10.5902/198050981922

Bart S, Roudine S, Amossé J, Mougin C, Péry ARR, Pelosi C (2018) How to assess the feeding activity in ecotoxicological laboratory tests using enchytraeids? Environ Sci Pollut Res 25:33844-33848. https://doi.org/10.1007/s11356-018-1701-3

Bicho RC, Santos FC, Gonçalves MF, Soares AM, Amorim MJ (2015) Enchytraeid Reproduction Test PLUS: hatching, growth and full life cycle test-an optional multi-endpoint test with Enchytraeus crypticus. Ecotoxicology 24:1053-1063. https://doi.org/10.1007/ s10646-015-1445-5

Bicho RC, Ribeiro T, Rodrigues NP, Scott-Fordsmand JJ, Amorim MJB (2016) Effects of Ag nanomaterials (NM300K) and Ag salt (AgNO3) can be discriminated in a full life cycle long term test with Enchytraeus crypticus. J Hazard Mater 318:608-614

Bicho RC, Scott-Fordsmand JJ, Amorim MJ (2020) Multigenerational exposure to WCCo nanomaterials-epigenetics in the soil invertebrate Enchytraeus crypticus. Nanomaterials 10:836 https://doi. org/10.3390/nano10050836

Botelho RG, Torniselo VL, Olinda R, Maranho LA (2012) Acute toxicity of sugarcane vinasse to aquatic organisms before and after $\mathrm{pH}$ adjustment. Toxicol Environ Chem. https://doi.org/10.1080/ 02772248.2012 .738516

Bourdeau PF (1953) A test of random versus systematic ecological sampling. Ecology 34:499-512

Castro GB, Pinheiro FR, Felipe MC, Bernegossi AC, Girolli D, Gorni GR, Corbi JJ (2020a) Update on the use of Pristina longiseta Ehrenberg, 1828 (Oligochaeta: Naididae) as a toxicity test organism. Environ Sci Pollut Res, 27:1-10. https://doi.org/10.1007/ s11356-020-10295-0

Castro GB, Bernegossi AC, Pinheiro FR, Felipe MC, Corbi JJ (2020b) Effects of Polyethylene Microplastics on Freshwater Oligochaeta Allonais inaequalis (Stephenson, 1911) Under Conventional and Stressful Exposures. Water Air Soil Pollution 231(475) https:// doi.org/10.1007/s11270-020-04845-y

Castro-Ferreira MP, Roelofs D, van Gestel CA, Verweij RA, Soares AM, Amorim MJ (2012) Enchytraeus crypticus as model species in soil ecotoxicology. Chemosphere, pp 1222-1227. https://doi. org/10.1016/j.chemosphere.2012.01.021
Chao A, Colwell RK, Lin CW, Gotelli NJ (2009) Sufficient sampling for asymptotic minimum species richness estimators. Ecology 90:1125-1133. https://doi.org/10.1890/07-2147.1

Chapman PM (2001) Utility and relevance of aquatic oligochaetes in Ecological Risk Assessment. In: Rodriguez P, Verdonschot PFM (eds) Aquatic Oligochaete Biology VIII. Developments in Hydrobiology edn. Springer, Dordrecht. https://doi.org/10.1007/97894-010-0597-5_17

Chu B, Zhang ZF, Zhou JW, Wang T, Hua LM (2018) Sampling method and sample size for studying soil physical property: A case of alpine meadow in eastern Qilian Mountain. Chinese Journal of Ecology 37

Domene X, Chelinho S, Campana P, Natal-da-Luz T, Alcañiz JM, Andrés P, Römbke J, Sousa P (2011) Influence of soil properties on the performance of Folsomia candida: Implications for its use in soil ecotoxicology testing. Environ Chem 30:1497-1505

Da Rocha AG, Pitombo LM, Bresolin JD et al (2020) Single and combined toxicity of the pesticides abamectin and difenoconazole on soil microbial activity and Enchytraeus crypticus population. SN Appl Sci. https://doi.org/10.1007/s42452-020-3175-4

DePatta VP (1998) Sampling sufficiency in ecological surveys. Abstracta Botanica 22:37-48. Retrieved September 10, 2020, from http://www.jstor.org/stable/43518936. DOI: https://doi.org/ $10.2307 / 43518936$

Droge ST, Paumen ML, Bleeker EA, Kraak MH, van Gestel CA (2006) Chronic toxicity of polycyclic aromatic compounds to the springtail Folsomia candida and the enchytraeid Enchytraeus crypticus. Environ Toxicol Chem 25:2423-2431. https://doi.org/10.1897/ 05-628R.1

Elphick CS (2008) How you count counts: the importance of methods research in applied ecology. J Appl Ecol 45:1313-1320. https:// doi.org/10.1111/j.1365-2664.2008.01545.x

Felipe MC, Bernegossi AC, Castro GB, Pinheiro FR, Nadai BL, Cardoso-Silva BN, Corbi JJ (2020) The use of an Allonais inaequalis reproduction test as an ecotoxicological bioassay. Ecotoxicology 29:634-638. https://doi.org/10.1007/s10646-020-02232-1

Fuess LT, Garcia ML (2014) Implications of vinasse land disposal: a critical review on the impacts of fertigation. J Environ Manage 145:210-229. https://doi.org/10.1016/j.jenvman.2014.07.003

Fuess LT, Rodrigues IJ, Garcia ML (2017) Fertirrigation with sugarcane vinasse: Foreseeing potential impacts on soil and water resources through vinasse characterization. J Environ Sci Hea Part A 52(11):1063-1072. https://doi.org/10.1080/10934529. 2017.1338892

Goedickemeier I, Wildi O, Kienast F (1997) Sampling for vegetation survey: some properties of a GIS-based stratification compared to other statistical sampling methods. Coenoses 12:43-50

Gomes SI, Gonçalves MF, Bicho RC, Roca CP, Soares AM, ScottFordsmand JJ, Amorim MJ (2018) High-throughput gene expression in soil invertebrate embryos-Mechanisms of Cd toxicity in Enchytraeus crypticus. Chemosphere 212:87-94. https://doi.org/ 10.1016/j.chemosphere.2018.08.068

Gregoire TG, Affleck DL (2018) Estimating desired sample size for simple random sampling of a skewed population. Am Stat 72:184-190

Hammer Ø, Harper DAT, Ryan PD (2001) past: paleontological statistics software package for education and data analysis. Palaeontologia Electronica 4:1-9

Henderson PA (2009) Practical methods in ecology. John Wiley \& Sons

Hrdá K, Opršal J, Knotek P, Pouzar M, Vlček M (2016) Toxicity of zinc oxide nanoparticles to the annelid Enchytraeus crypticus in agar-based exposure media. Chem Pap 70:1512-1520. https://doi. org/10.1515/chempap-2016-0080

Jänsch S, Römbke J, Didden W (2005) The use of enchytraeids in ecological soil classification and assessment concepts. Ecotox environ safe 62:266-277. https://doi.org/10.1016/j.ecoenv.2004.10.025 
Kaur A, Patil GP, Shirk SJ, Taillie C (1996) Environmental sampling with a concomitant variable: a comparison between ranked set sampling and Strati ${ }^{\circledR}$ ed simple random sampling. J Appl Stat 23:231-255. https://doi.org/10.1080/02664769624224

Lahive E, Walton A, Horton AA, Spurgeon DJ, Svendsen C (2019) Microplastic particles reduce reproduction in the terrestrial worm Enchytraeus crypticus in a soil exposure. Environ Pollut 255:113174. https://doi.org/10.1016/j.envpol.2019.113174

Matějů V, Vosáhlová S, Kyclt R, Janoch T, Šedivcová G (2014) The reproduction of Enchytraeus sp.- - technical improvement for the counting of juveniles. Environ Monit Asses 186:711-718. https:// doi.org/10.1007/s10661-013-3409-7

Mendonça MCP, de Jesus MB, van Gestel CA (2020) Protective effect of $\mathrm{N}$-acetylcysteine on the toxicity of silver nanoparticles: Bioavailability and toxicokinetics in Enchytraeus crypticus. Sci Total Environ. https://doi.org/10.1016/j.scitotenv.2020.136797

Mode NA, Conquest LL, Marker DA (1999) Ranked set sampling for ecological research: accounting for the total costs of sampling. Environmetrics 10:179-194

Newman MC (2009) Fundamentals of ecotoxicology. CRC press

Niemeyer JC, Chelinho S, Sousa JP (2017) Soil ecotoxicology in Latin America: Current research and perspectives. Environ Toxicol Chem 36:1795-1810. https://doi.org/10.1002/etc.3792

OECD (Organisation for Economic Co-Operation and Development) (2016) Test No 220: Enchytraeid Reproduction Test. OECD Publishing, Paris. https://doi.org/10.1787/9789264264472-en

OECD (Organisation for Economic Co-operation and Development) (1984) Guidelines for testing of chemicals No. 207. Earthworm, acute toxicity test. OECD, Paris. https://doi.org/10.1787/20745 761

Pflugmacher S, Huttunen JH, Wolff MAV, Penttinen OP, Kim YJ, Kim S, Mitrovic SM, Esterhuizen-Londt M (2020) Enchytraeus crypticus avoid soil spiked with microplastic. Toxics. https://doi.org/ $10.3390 /$ toxics 8010010

Rombke J (2003) Ecotoxicological laboratory tests with enchytraeids: A review. Pedobiologia. https://doi.org/10.3897/zookeys.801. 21970

Roembke J, Schmelz RM, Pelosi C (2017) Effects of organic pesticides on enchytraeids (Oligochaeta) in agroecosystems: laboratory and higher-tier tests. Frontiers in Environmental Science. https://doi. org/10.3389/fenvs.2017.00020

R Core Team (2014) R: a language and environment for statistical computing. R Foundation for Statistical Computing, Vienna, Austria, http://www.R-project.org/

Sivakumar S (2015) Effects of metals on earthworm life cycles: a review. Environ Monit Assess. https://doi.org/10.1007/ s10661-015-4742-9

Testa M, da Silva AS, Segat JC, Maluche-Baretta CR, Baretta D (2020) Impacts on reproduction of Enchytraeus crypticus in fertilized soils with chicken litter treated with synthetic and natural insecticide. Environ Toxicol Phar. https://doi.org/10.1016/j.etap.2020. 103386

Topoliantz S, Ponge JF, Viaux P (2000) Earthworm and enchytraeid activity under different arable farming systems, as exemplified by biogenic structures. Plant Soil 225:39-51. https://doi.org/10. 1023/A:1026537632468

Trauspurger W, Haitzer M, Höss S, Beier S, Ahlf W, Steinberg C (2009) Ecotoxicological assessment of aquatic sediments with Caenorhabditis elegans (nematoda) - a method for testing liquid medium and whole-sediment samples. Environ Toxicol Chem. https://doi.org/10.1002/etc.5620160221

USEPA - UNITED STATES ENVIRONMENTAL PROTECTION AGENCY. Methods for Measuring the Acute Toxicity of Effluents and Receiving Waters to Freshwater and Marine Organisms. p. 1-275, 2002

Westheide W, Graefe U (1992) Two new terrestrial Enchytraeus species (Oligochaeta, Annelida). J Nat Hist 26:479-488

Zaghloul A, Saber M, Gadow S et al (2020) Biological indicators for pollution detection in terrestrial and aquatic ecosystems. Bull Natl Res Cent. https://doi.org/10.1186/s42269-020-00385-x

Zhou H, Xiang N, Xie J, Diao X (2018) Ecotoxicology: the history and present direction. Encyclop Ecol 2:1-9

Publisher's Note Springer Nature remains neutral with regard to jurisdictional claims in published maps and institutional affiliations. 